\title{
Image and sport: exhibition of brazilian athletes on the instagram social network
}

\author{
Vivian de Oliveira', Ivan Wallan Tertuliano², José Maria Montiel', Daniel Bartholomeu, Afonso Antonio Machado ${ }^{4}$
}

\begin{abstract}
Background: Social networks have changed the dynamics of society in communication, commercial and social relations, advertising, among others. In sports, this would not be different. Along with this, the new media open up new possibilities for exploration of the image of the athlete, since traditional media conduct different treatments for male and female athletes. Objective: To verify the posts made on Instagram by Brazilian athletes and to verify if there are differences related to the gender of the athletes in the contents posted. Methods: The subjects selected for this research were Brazilian athletes and medalists of the 2012 Summer Olympics. The data were obtained through the collection of the images that the athletes posted on the Instagram and after that, the analysis of the images were made with the use of a checklist created for that study. Results: The results indicated that male and female did not present differences between categories of posted images. The most common type of images posted are the images in which the athlete is present, in places related to their work and in moments of relaxation. It also highlights the fact that most of the images posted do not make any reference to the sponsorships of the athletes. Conclusion: Therefore, it can be concluded that male and female have the same behavior of photo posting on social networks. It is also observed that the potential of social networks for advertising is still little explored by Brazilian athletes. Due to the originality of this work and because it seems to be a very pertinent theme in the present day, it is suggested the extension of this study.
\end{abstract}

Keywords: Instagram; Athletes; Human Development; Image; Sport.

\section{INTRODUCTION}

For Keen ${ }^{(1)}$, the internet is where we live today. In this way, looking at the internet, it can be seen something that reflects not only ourselves but also the dominant values of the society. According to McLuhan ${ }^{(2)}$, the presence of the media configures another way of existing socially. Inserted in this new reality, it can be found the social networks. According to Piza ${ }^{(3)}$, "the social networks on the Internet appear as a network of factors formed by social interaction that is mediated by a technical device with access to the internet". For the author, social networks allow the creation of new social groups called virtual communities, which are new forms of collective insertions in cyberspace. Virtual social networks change the dynamics of marketing, commerce, social relations and the boundaries between public and private. According to Keen ${ }^{(1)}$ the desire for privacy was considered the dominant cultural norm in the industrial era, but today it seems to be different: "we want everyone to watch us". Instagram is one of many existing social networks. Instagram is a social networking app that allows the user to publish photos and videos made with their mobile devices over the network. You can also manipulate photos and videos by applying filters and other basic editing tools. Instagram has interface with other social networks, like
Facebook and Twitter, which expands the propagation of the contents. Released on October 6, 2010, Instagram exceeds 500 million users, making it the second largest social network, behind Facebook ${ }^{(4)}$.

One of the differentials of Instagram in relation to other social networks is that it can only be used through mobile devices. To post a photo, the user can take it directly using the camera of their mobile device, use a picture that is already saved on the device, or use photographs that have been made with other devices, such as digital cameras, for example. Another differential, according to Linaschke ${ }^{(5)}$, is the focus on the picture. Although other social networks, such as Facebook and Twitter for example, also allow the sharing of photos and videos, only on Instagram the focus is the visual. This is made clear by the fact that on Instagram it is not possible to post without a photo or video. Sport is a male-dominated environment, since the days of Ancient Greece. For Camargo, Bragion and Vendite ${ }^{(6)}$, the female sport in the country continues to giving in to social pressures, in which women play a secondary role in relation to the male sport. To prove this fact, some studies show us that the sports press treats differently women and men who participate in the 
sports universe ${ }^{(7-9)}$. The authors affirm that the Brazilian sports media tends to value the physical aspects of female athletes, focusing on aesthetic and physical beauty, leaving sports performance in the background, a fact that does not occur with men. As the new media have given new opportunities to people, increasingly decentralizing the control of information publications, do social networks still have these differences? Therefore, the objective of this study was to verify the posts made on Instagram by Brazilian athletes and to verify if there are differences related to the gender of the athletes in the contents posted.

\section{METHODS}

This is a qualitative-quantitative research, of the descriptive type, which uses the netnographic method for data collection and is based on Visual Sociology ${ }^{(10,11)}$. The athletes selected for the analyzes were the Brazilian Olympic medalists in London 2012. This sample was chosen because they are elite athletes and have received some media attention for their achievements in 2012 and, in addition, Instagram gained notoriety as a social application since 2011, popularizing its use, thus, the use of this time period is an important factor for research on the Instagram social network with Olympic athletes. The total number of Brazilian athletes who were medalists in the Summer Olympic of 2012 is 58 athletes, of individual and collective modalities. From this initial number, athletes who do not have an Instagram profile, or have a private profile (when authorization is required from the profile owner to view their photos) were excluded from the survey, which means that the total number of subjects was 40 athletes. Of the 40 athletes who fulfilled the requisites for the research, 1 is of artistic gymnastics mode, 2 are of judo, 19 of volleyball, 2 of boxing, 13 of male football, 2 of swimming and 1 of modern pentathlon. And 12 athletes are females and 28 are males. To assist in this process, an analysis protocol was created, in a checklist format, which includes items pertinent to the purpose of the research. The instrument has seven categories, which are: photo type, location, moment, sponsorships, hashtags, emphasis on the body, emphasis on the garb. For the certification of its qualities for the objective it proposes, the checklist was developed with the participation of 3 judges, all doctors and with more than 10 years of experience in netnographic research, with the purpose of minimizing possible failures. Because it was a netnographic research, there was no need for authorization from the Ethics and Research Committee. To perform the data collection, initially, a profile was created in the Instagram specifically for this analysis. The selected athletes were "followed" on the social network by the profile created for this research.

The photos collection began in January 2015 and ended in May 2015, which totaled a period of 4 months of photo collection. The photos were collected daily, as the athletes published on their accounts. The photos posted before this period were not considered in this research. Although it is considered interesting the analysis of the photos posted by the athletes during the period of the Summer Olympic 2012, this was not possible due to limitations of the application itself. The period used in this study corresponded to the period of preparation of some athletes for the Pan American Games in Toronto that occurred in July 2015. After the photos were collected, they were analyzed using the aforementioned checklist. As an inferential analysis of the information obtained by the checklist, the t-test for independent samples was used for analyzes between groups (male $X$ female). The analyzes were performed by the IBM SPSS Statistics software, version 20 , assuming the alpha value of 0.05 for significant differences.

\section{RESULTS}

The results were presented with the use of descriptive and inferential information and, in addition, presented by category of photos, according to the checklist, in order to favor the understanding of the reader. In relation to the photos posted, females posted a total of 667 photographs, while males posted a total of 1348 photographs, totaling 2015 photographs posted.

Of these 2015 photographs, $66.90 \%$ represents the males' posting and $33.10 \%$ the females' posting. These data present the male as the athletes who most use Instagram for posting photographs. The t test for independent samples did not present a significant difference between the genders $(p=0.677)$. About the type of photos that appear in the post, the female group posted $44.80 \%$ of the total only photos in which they appear, with or without people present in the photo. Then there are the montages with $18 \%$ of the total posts, selfies with $10.3 \%$, selfies with just the athletes with $9.9 \%$, memes with $5 \%$, third-party photographs with $2.7 \%$, objects with $2.2 \%$, pets with $1.9 \%$, landscapes with $1.3 \%$, and finally, foods with $1 \%$. In the female group, $2.8 \%$ of the photographs posted were in the "Others" category. When it comes to the male group, of the 1.348 images published by them, $51.3 \%$ are also of the athletes. Then there are selfies with other people $(51.3 \%)$, montages $(12 \%)$, selfies with just the athlete $(6.5 \%)$, third-party photographs $(5 \%)$ and objects $(2,4 \%)$. Memes and landscape photographs were tied with $1.6 \%$ of the publications, followed by foods $(1.2 \%)$ and pets $(0.7 \%)$. The "Other" category was with $3.8 \%$ of total photographs.

Although analyzes using descriptive statistics may suggest a different pattern of postings for male and female athletes, when we submitted the data to the inferential analysis (T-test for independent samples), it was verified that the differences did not remain for this category ( $p>0.05)$, as shown in table 1. These results indicate that there are no significant differences between male and female in any categories.

As for the places where the photos were taken, for males, $40.1 \%$ of the photos were taken in the training centers, 
changing rooms, gymnasiums, among others. For females, this category includes $32.2 \%$ of published photos. On the other hand, the category "Leisure places" comprises $13.7 \%$ of the photos published by males and $17.1 \%$ by females. The total of $9.9 \%$ of the photos of males and $10 \%$ of the photos of females were made in their houses. The means of transportation were the places of $5.4 \%$ of the photos published by males and $3.3 \%$ of those published by females. The "Gym" category covers $1.7 \%$ and $2.1 \%$ of the photographs posted by males and females respectively. For men, $11.5 \%$ of the images were classified as "Other" and $17.5 \%$ as "Cannot be defined". For females, $12.5 \%$ of the images were classified as "Other" and $22.7 \%$ as "Cannot be defined". In the "Place" category, no significant differences were found for men and women (T-test for independent samples), according to the inferential analysis ( $p>0.05)$, as shown in table 2.

At the "moment" in which the photos were taken, 50\% of them were taken at relaxation, $26.3 \%$ at work, $14.4 \%$ at leisure, $2.3 \%$ at rest. For females, $54.5 \%$ of them were taken at relaxation, $18.1 \%$ at work, $16 \%$ at leisure and $3.7 \%$ at rest.
The "Cannot be defined" category had 7.1\% of the photos posted by males and $7.7 \%$ posted by females. Also for this category, the T-test for independent samples did not show significant differences between males and females ( $p>0.05)$, as shown in table 3.

In the sponsorship category, for male athletes, $39.5 \%$ of the photos have some reference to their sponsorships, while for female athletes this total is $37.4 \%$. In the hashtags category, the presence of hashtags was present in $52.9 \%$ of the males' publications and in $56.8 \%$ of the females' publications.

Regarding the "emphasis on the body" category, the body appears in $6.5 \%$ of the photos posted by males, and $4.4 \%$ by females. In the "emphasis on the garb" category, the posted photos represent $3.9 \%$ posted by males and $9.4 \%$ posted by females.

For all these categories (sponsorships, hashtags, emphasis on the body and the garb), no significant differences were found between males and females, that is, the T-test for independent samples presented $\mathrm{p}$ values $\mathbf{0 . 0 5}$ in all categories.

Table 1: Analysis between groups for photo posting $(n=40)$

\begin{tabular}{|c|c|c|c|c|c|}
\hline Variable** & Group & $\mathbf{N}$ & Mean & SD & $\begin{array}{l}\text { T test for independent } \\
\text { samples }\end{array}$ \\
\hline \multirow{2}{*}{$\begin{array}{l}\text { The athlete (the athlete herself/himself, with or } \\
\text { without other people in the picture) }\end{array}$} & Female & 12 & 24.68 & 25.607 & \multirow{2}{*}{0.677} \\
\hline & Male & 28 & 25.25 & 27.079 & \\
\hline \multirow[t]{2}{*}{ Selfies (just the athlete) } & Female & 12 & 3.11 & 4.246 & \multirow{2}{*}{0.950} \\
\hline & Male & 28 & 5.58 & 7.403 & \\
\hline \multirow[t]{2}{*}{ Selfies (with other people) } & Female & 12 & 6.75 & 10.564 & \multirow{2}{*}{0.296} \\
\hline & Male & 28 & 5.83 & 7.334 & \\
\hline
\end{tabular}

Table 2: Analysis between groups for photo posting in the 'Place' category $(n=40)$

\begin{tabular}{|c|c|c|c|c|c|}
\hline Variable** & Group & $\mathbf{N}$ & Mean & SD & $\begin{array}{l}\text { T test for independent } \\
\text { samples }\end{array}$ \\
\hline \multirow[t]{2}{*}{ Home } & Female & 12 & 3.71 & 4.250 & \multirow{2}{*}{0.695} \\
\hline & Male & 28 & 4.33 & 5.211 & \\
\hline \multirow[t]{2}{*}{ Training center } & Female & 12 & 15.04 & 16.444 & \multirow{2}{*}{0.836} \\
\hline & Male & 28 & 13.92 & 13.228 & \\
\hline \multirow[t]{2}{*}{ Gym } & Female & 12 & .64 & 1.026 & \multirow{2}{*}{0.499} \\
\hline & Male & 28 & .92 & 1.443 & \\
\hline \multirow[t]{2}{*}{ Leisure places } & Female & 12 & 5.14 & 5.797 & \multirow{2}{*}{0.311} \\
\hline & Male & 28 & 7.42 & 7.740 & \\
\hline \multirow[t]{2}{*}{ Means of transport } & Female & 12 & 2.04 & 2.874 & \multirow{2}{*}{0.505} \\
\hline & Male & 28 & 1.42 & 2.065 & \\
\hline \multirow[t]{2}{*}{ Cannot be defined } & Female & 12 & 6.57 & 10.465 & \multirow{2}{*}{0.400} \\
\hline & Male & 28 & 9.83 & 12.561 & \\
\hline \multirow[t]{2}{*}{ Others } & Female & 12 & 4.32 & 7.674 & \multirow{2}{*}{0.692} \\
\hline & Male & 28 & 5.42 & 8.554 & \\
\hline
\end{tabular}


Table 3: Analysis between groups for photo posting in the 'Moment' category $(n=40)$

\begin{tabular}{|c|c|c|c|c|c|}
\hline Variable** & Group & $\mathbf{N}$ & Mean & SD & $\begin{array}{l}\text { T test for independent } \\
\text { samples }\end{array}$ \\
\hline \multirow[t]{2}{*}{ Work } & Female & 12 & 9.86 & 10.662 & \multirow{2}{*}{0.547} \\
\hline & Male & 28 & 7.83 & 6.562 & \\
\hline \multirow[t]{2}{*}{ Rest } & Female & 12 & .86 & 1.268 & \multirow{2}{*}{0.396} \\
\hline & Male & 28 & 1.58 & 2.746 & \\
\hline \multirow[t]{2}{*}{ Leisure } & Female & 12 & 5.39 & 5.466 & \multirow{2}{*}{0.470} \\
\hline & Male & 28 & 6.92 & 7.280 & \\
\hline \multirow[t]{2}{*}{ Relaxation } & Female & 12 & 18.71 & 22.216 & \multirow{2}{*}{0.553} \\
\hline & Male & 28 & 23.58 & 26.668 & \\
\hline \multirow[t]{2}{*}{ Cannot be defined } & Female & 12 & 2.64 & 3.223 & \multirow{2}{*}{0.627} \\
\hline & Male & 28 & 3.33 & 5.678 & \\
\hline
\end{tabular}

\section{DISCUSSION}

Regardless of the differences between male and female, the results indicate that the most common type is the photos in which the athletes are present, whether they are taken by themselves or by another person. This fact corroborates the findings of Bakhshi, Shamma and Gilbert ${ }^{(12)}$, who state that one of the most common types of shared photo content on social media is the photos of people or with human faces. The research done by the authors showed that photos with human faces are $38 \%$ more likely to receive likes, are $32 \%$ more likely to receive comments, and that the number of faces present on the photo, age and gender of those who are there have no effect on these numbers. Faced with this, it is worth saying that the photos with faces cause what the authors call engagement in communities of image sharing ${ }^{(12)}$. Another result that catches our attention is the data regarding the exposure of the body and the clothes of the athletes. While studies previously cited ${ }^{(8,9)}$ show that traditional media tends to highlight the beauty and physical attributes of athletes, we realize that this does not happen when athletes themselves show up on social networks.

To exemplify this situation, we cited the study of Pereira, Pontes and Ribeiro ${ }^{(7)}$, whose objective was to analyze the images exhibited in the "O Globo" and "O Dia" newspapers during the Summer Olympic of London 2012, seeking to clarify how these newspapers exhibited masculine and feminine images during the Games. The authors found differences related to the gender of the athletes in the images present in the articles published by the newspapers, and concluded that journalistic coverage continues to reproduce "stereotypes, prejudices, sexism, resistance and even new values and attitudes that exalt dominant views between men and women in society nowadays". The results of this study confront this view, showing that there are no statistically significant differences in the posting profile between male and female athletes. On the sponsorships, in the qualitative analysis, we could explain this difference in the percentages based on the financial discrepancy between the male and the female sport. Male and female living in the sport receive differentiated salaries and awards, with male athletes taking advantage of this issue ${ }^{(13)}$. According to Gibson ${ }^{(14)}$ in an article published in the British newspaper "The Guardian", elite female sports sponsorship in the UK was only $0.5 \%$ of the total market between January 2010 and August 2011, and the male sports was $61.1 \%$, with mixed sports representing the rest of the market. However, when the findings are submitted to the inferential analysis, it can be observed that these differences do not remain, which leads us to the idea of tendency, explanations about the sponsors, and not confirmation of them.

In general, the results indicate that the potential for marketing of social networks, specifically Instagram, is poorly explored by Brazilian athletes. In the program "Esporte Espetacular" (Rede Globo de Televisão), on March 26, $2017^{(15)}$, was quoted the case of Poliana Okimoto, athlete of the aquatic marathon, who pays the expenses of her preparation with her own money. The program pointed to the fact of the image underutilization of the athlete. According to the report, neither the club where the athlete trains, nor the gym she frequents use the image of the athlete for advertising, in an attempt to attract new clients and consequently generate a new source of income for the athlete. This is a waste of possibilities, since social networks could be a means for the propagation of the winning image of the athlete, with Poliana Okimoto as a pitchwoman, generating a return to all sides involved.

\section{Considerations}

Contrary to what we might have imagined at the beginning of this research, based on the findings of other researchers who conducted their investigations based on traditional media, the way Brazilian athletes represent themselves in 
their social networks (specifically Instagram) follows the same pattern for both genders. This tells us that the sexualization of athletes and the appeal to the physical and the beautiful that is often evidenced in so-called traditional media such as newspapers, TV, news portals, among others, is not repeated on social networks, an environment in which it is believed that the athletes have a domain over what is published. This fact proves the tendentious character of the traditional media in the treatment of female athletes, with the objective of "selling the newspaper", since the sport is still a content consumed mainly by men.

Another important consideration at the end of this paper is on the issue of sponsorship, as athletes rarely explore their commercial images through social networks, specifically Instagram. We know that social networks have great potential for marketing, including sports marketing, but in the case of Brazilian athletes, this potential is still little used. We believe that this is a lost possibility, because with the current crisis of Brazilian sport and the difficulty in guaranteeing a sponsor for our athletes, the use of their images through Instagram can be a new source of income. Due to the originality of this work and because it seems to be a very pertinent theme in the present day, it is suggested the extension of this study. As new possibilities we highlight the approach with athletes from different countries/cultures at different competitive moments, and a greater exploration of the subtitles (the textual content) of the images.

\section{CONCLUSION}

From this work, it can be seen that Instagram reinforces this need of people to posting on social networks today. This pattern is repeated with athletes, since the data reveal that the athletes are showing up in the vast majority of the photos posted.

\section{AUTHORS' CONTRIBUTIONS}

VO: study design; IWT, JMM, DB, AAM: data collection; VO, AAM: critical intellectual review of the manuscript; IWT, JMM, DB: results writing. All the authors wrote the discussions and conclusions. Finally, all authors read and approved the final manuscript.

\section{COMPETING INTERESTS}

The authors declare that they have no competing interests.

\section{AUTHORS DETAILS}

${ }^{2}$ Centro Universitário Adventista de São Paulo (UNASP), São Paulo (SP), Brasil

${ }^{3}$ Centro Universitário Salesiano de São Paulo (UNISAL), Americana (SP), Brasil

${ }^{4}$ Universidade Estadual Paulista (UNESP), Rio Claro (SP), Brasil

\section{REFERENCES}

1. Keen A. Vertigem digital: por que as redes sociais estão nos dividindo, diminuindo e desorientando? Rio de Janeiro: Zahar; 2012.

2. MCluhan M. Os meios de comunicação como extensões do homem. 14th ed. São Paulo: Cultrix; 2005.

3. Piza MV. O fenômeno Instagram: considerações sob a perspectiva tecnológica. [Monografia de Conclusão de Curso]. Brasília: Universidade de Brasília. Faculdade de Ciências Sociais; 2012.

4. G1. Instagram ultrapassa os 500 milhões de usuários [Internet]. Globo. com. 2016 [cited 2017 Jan 21]. Available from: http://g1.globo.com/ tecnologia/noticia/2016/06/instagram-ultrapassa-os-500-milhoes-deusuarios.html

5. Linaschke J. Getting the most from Instagram. Berkeley: Peachpit Press; 2011.

6. Camargo VRT, Bragion LHA, Vendite CC. A construção midiática da imagem e da mulher no esporte e suas conquistas sociais. In: Marques JC, editor. Comunicação e esporte: diálogos possíveis. São Paulo: Intercom; 2007; 172-83.

7. Pereira EGB, Pontes VS, Ribeiro CHV. Jogos Olímpicos de Londres 2012: brasileiros e brasileiras em foco. Rev Educ Física/UEM. 2014; 25(2): 257-71.

8. Romero E, Miragaya AMF, Ribeiro CHV, Pereira EGB. O olhar da imprensa sobre o vôlei feminino: quando a sombra se destaca. Salusvita. 2014; 33(1): 17-44.

9. Romero E, Pereira EGB, Sant'anna KBS. Mulheres na imprensa esportiva: imagens e palavras. Salusvita. 2014; 33(3): 285-308.

10. Ferro L. Ao Encontro da Sociologia Visual. Rev da Fac Let da Univ do Porto. 2005; 15: 373-98.

11. Martins JS. Sociologia da Fotografia e da Imagem. 2nd ed. São Paulo: Editora Contexto; 2013.

12. Bakhshi S, Shamma DA, Gilbert E. Faces Engage Us: photos with faces attract more likes and comments on Instagram. In: SIGCHI Conference. Toronto: SIGCHI; 2014; 965-74.

13. Moraes V, Antonielli R. Mulheres ainda amargam salários e premiações inferiores aos dos homens [Internet]. Superesportes. com.br. 2014. Available from: http://www.superesportes.com.br/ app/19,66/2014/03/08/noticia_maisesportes,53274/mulheres-aindaamargam-salarios-e-premiacoes-inferiores-aos-dos-homens.shtml

14. Gibson O. Women's sport 'attracts $0.5 \%$ of all sponsorship, 2011 [Internet]. www.theguardian.com. 2011 [cited 2016 Jan 8]. Available from: https:// www.theguardian.com/tv-and-radio/2011/nov/05/women-sport-pointfive-sponsorship

15. GLOBO. E agora? Queda dos investimentos em esportes olímpicos afeta diretamente atletas [Internet]. globoplay.com. 2017 [cited 2017 Mar 26]. Available from: https://globoplay.globo.com/v/5753899/ 